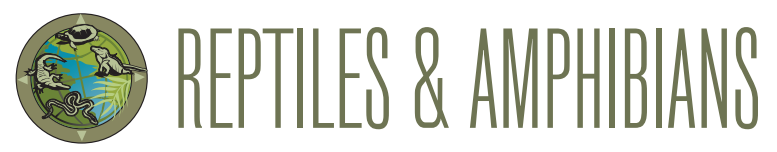

\title{
A Freshwater Crab (Barytelphusa cunicularis) Feeding on Amboli Leaping Frog (Indirana chiravasi) Larvae in Maharashtra, India
}

\author{
Omkar Yadav
}

Amdar Shashikant Shinde Mahavidyalaya, Medha, Satara, Maharashtra, India (sarpaveda@gmail.com)

$\mathrm{N}$ atural selection, food web structure, population dynamics, community assemblages, and ecosystem function are all influenced by predator-prey interactions (Portalier et al. 2019). McCormick and Polis (1982) conducted a comprehensive global review of arthropod predation, in which they determined that arthropods were significant and underappreciated predators of vertebrates. Most if not all stages of amphibian life cycles are vulnerable to predation by arthropods but knowledge of the predation risk to and beyond metamorphosis is sparse (Nyffeler and Altig 2020; Valdez 2020).

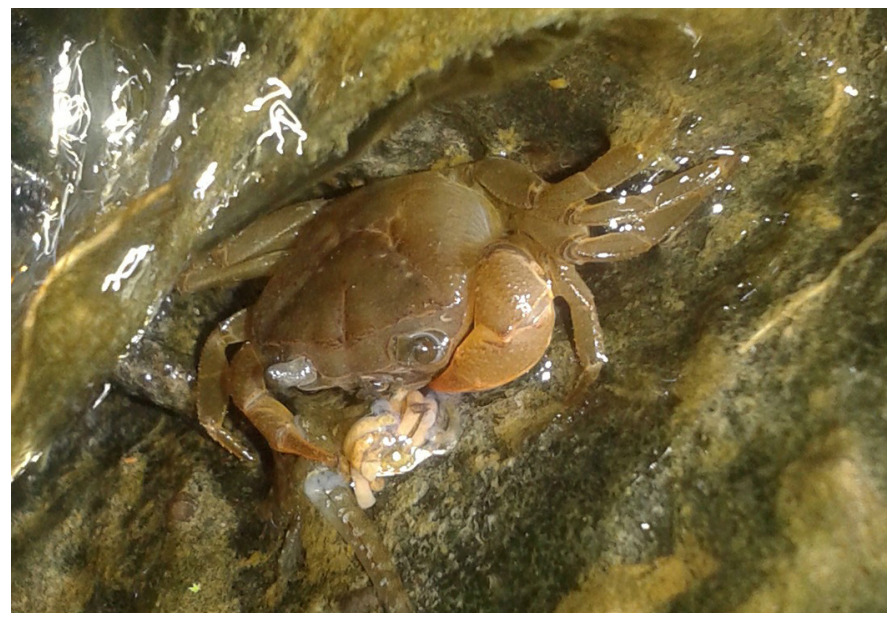

Fig. 1. A freshwater crab (Barytelphusa cunicularis) feeding on Amboli Leaping Frog (Indirana chiravasi) tadpoles near the Rangana Fort in the Sahyadri Mountains in Maharashtra, India. Photograph by Omkar Yadav.
The terrestrial larvae of the Amboli Leaping Frog (Indirana chiravasi), an endemic of the northern Western Ghats, inhabit areas with large wet rocks (Padhye et al. 2014). During a herpetological expedition on 18 July 2015, colleagues and I encountered a freshwater crab (Barytelphusa cunicularis) feeding on Amboli Leaping Frog tadpoles in a rocky crevice near the Rangana Fort in the Sahyadri Mountains on the boundary of Kolhapur and Sindhudurg Districts in Maharashtra, India $\left(16.0849^{\circ} \mathrm{N}, 73.8437^{\circ} \mathrm{E}\right.$; WGS84; $633 \mathrm{~m}$ asl). To the best of my knowledge, this is the first report of $B$. cunicularis feeding on I. chiravasi tadpoles.

\section{Acknowledgement}

I thank Amrut Bhosale and Tejas Patil for assistance in the field.

\section{Literature Cited}

McCormick, S. and G.A. Polis. 1982. Arthropods that prey on vertebrates. Biological Reviews 57: 29-58. https://doi.org/10.1111/j.1469-185X.1982. tb00363.x.

Nyffeler, M. and R. Altig. 2020. Spiders as frog-eaters: a global perspective. The Journal of Arachnology 48: 26-42. https://doi.org/10.1636/0161-820248.1.26.

Padhye, A.D., N. Modak, and N. Dahanukar. 2014. Indirana chiravasi, a new species of Leaping Frog (Anura: Ranixalidae) from Western Ghats of India. Journal of Threatened Taxa 6: 6293-6312. https://doi.org/10.11609/JoTT. o4068.6293-312.

Portalier, S.M.J., G.F. Fussmann, M. Loreau, and M. Cherif. 2019. The mechanics of predator-prey interactions: First principles of physics predict predator-prey size ratios. Functional Ecology, 33: 323-334. https://doi.org/10.1111/13652435.13254 .

Valdez, J.W. 2020. Arthropods as vertebrate predators: A review of global patterns. Global Ecology Biogeography 2020.00: 1-13. https://doi.org/10.1111/ geb. 13157 . 